\title{
PENGARUH PEMBERIAN KOMBINASI PUPUK ORGANONITROFOS DAN PUPUK KIMIA DENGAN PENAMBAHAN BIOCHAR TERHADAP KEMANTAPAN AGREGAT TANAH ULTISOL DI NATAR DAN TAMAN BOGO
}

\author{
Aan Rinaldi ${ }^{1}$, Dermiyati ${ }^{2}$, Rianida Taisa ${ }^{2} \&$ Afandi $^{2}$ \\ ${ }^{1}$ Mahasiswa Jurusan Agroteknologi Fakultas Pertanian Universitas Lampung \\ ${ }^{2}$ Dosen Jurusan Agroteknologi Fakultas Pertanian Universitas Lampung \\ Jl. Prof. Dr. Soemantri Brodjonegoro No. 1 Bandar Lampung 35145 \\ Email: Aanrinaldi28@gmail.com
}

\begin{abstract}
ABSTRAK
Penelitian ini bertujuan untuk mengetahui kombinasi pupuk organonitrofos dan pupuk kimia dengan penambahan biochar yang paling efisien untuk memperbaiki kemantapan agregat tanah. Penelitian dilaksanakan di dua lokasi yaitu kebun percobaan BPTP(Balai Pengkajian Teknologi Pertanian) Provinsi Lampung dilaksanakan pada Juni 2016 sampai dengan September 2016 dan di kebun percobaan Taman Bogo Lampung Timur dilaksanakan dari April sampai dengan Juli 2016. Rancangan perlakuan menggunakan Rancangan Acak Kelompok (RAK) dengan 11 perlakuan dan 3 ulangan. Pengujian homogenitas ragam menggunakan uji Bartlett sedangkan uji aditifitas data menggunakan uji Tukey. Kemudian dilakukan uji standar devisiasi. Variabel yang diamati adalah kemantapan agregat dengan metode ayakan ganda (ayakan kering dan ayakan basah). Hasil penelitian menunjukkan bahwa kombinasi pupuk organonitrofos dan pupuk kimia dengan penambahan biochar yang paling efisien memperbaiki kemantapan agregat tanah di lokasi BPTP adalah $100 \%$ NPK + $100 \%$ OP yaitu 52,260. Sedangkan di lokasi Taman Bogo kombinasi pupuk organonitrofos dan pupuk kimia dengan penambahan biochar yang paling efisien untuk memperbaiki kemantapan agregat tanah adalah $75 \%$ NPK $+25 \%$ OP yaitu 53,143.
\end{abstract}

Kata kunci: Biochar, kemantapan agregat, organonitrofos, tanah ultisol.

\section{PENDAHULUAN}

Tanah Ultisol merupakan salah satu jenis tanah mineral masam yang berpotensi besar untuk perluasan dan peningkatan produksi pertanian di Indonesia. Kendala utama yang dijumpai dalam pengembangan Ultisol untuk lahan pertanian yaitu ketersediaan hara yang rendah. Ultisol mempunyai sebaran yang sangat luas, meliputi hampir $25 \%$ dari total daratan di Indonesia. Kandungan hara pada tanah Ultisol umumnya rendah karena pencucian basa berlangsung intensif, sedangkan kandungan bahan organik rendah karena proses dekomposisi berjalan cepat dan sebagian terbawa erosi sehingga dapat mengakibatkan kerusakan pada tanah (Prahastuti, 2005).

Kerusakan struktur tanah diawali dengan penurunan kemantapan agregat tanah, yang disebabkan oleh energi pukulan air hujan dan kekuatan limpasan permukaan. Penurunan kestabilan agregat tanah ini 
diakibatkan oleh penurunan kandungan bahan organik tanah, aktivitas perakaran tanaman dan mikroorganisme tanah akibat erosi. Penurunan ketiga agen pengikat agregat tanah tersebut selain menyebabkan agregat tanah relatif mudah pecah dan menyebabkan terbentuknya kerak di permukaan tanah (soil crusting) yang mempunyai sifat padat dan keras bila kering (Suprayogodkk., 2005).

Rendahnya unsur hara yang terkandung di tanah Ultisol dapat diatasi dengan beberapa cara, salah satu cara yang paling banyak dilakukan adalah dengan penambahan bahan organik. Bahan organik tanah merupakan salah satu penyusun atau pembentuk agregat tanah. Bahan organik ini berperan sebagai pelekat antar partikel tanah untuk nantinya bersatu menjadi agregat tanah. Penambahan bahan organik akan meningkatkan kemampuan menahan air sehingga kemampuan menyediakan air tanah untuk pertumbuhan tanaman meningkat (Suntoro, 2003).

Penambahan bahan organik dapat menurunkan bulk density tanah karena membentuk agregat tanah yang lebih baik dan memantapkan agregat yang telah terbentuk sehingga aerasi, permeabilitas dan infiltrasi menjadi lebih baik. Pemberian pupuk organik merupakan salah satu cara untuk menambahkan bahan organik pada tanah Ultisol yang berfungsi untuk mengganti kehilangan unsur hara pada media atau tanah.

Pupuk organonitrofos merupakan pupuk alternatif yang berbasis bahan organik. Pupuk organik dan bahan organik merupakan sumber nitrogen tanah, selain itu peranannya cukup besar terhadap perbaikan sifat biologi, kimia, dan fisika tanah. Pupuk organik yang ditambahkan ke dalam tanah akan mengalami perombakan oleh mikroorganisme tanah untuk menjadi bahan organik tanah, selain pupuk organik, pemberian pupuk anorganik juga dapat memperbaiki kerusakan tanah Ultisol. Pupuk anorganik adalah pupuk yang mengandung satu atau lebih unsur hara. Fungsi utama pupuk anorganik adalah sebagai penambah unsur hara atau nutrisi tanaman. Sering dijumpai beberapa kelebihan dan kelemahan pupuk anorganik. Beberapa manfaat dan keunggulan pupuk anorganik antara lain mampu menyediakan hara dalam waktu relatif lebih cepat, menghasilkan nutrisi lebih banyak, tidak berbau menyengat, praktis dan mudah diaplikasikan. Sedangkan kelemahannya yaitu harga relatif mahal dan mudah larut, menimbulkan polusi pada tanah apabila diberikan dalam dosis yang tinggi (Leiwakabessy dan Sutandi, 2004).

Penambahan biochar pada tanah berfungsi sebagai pembenah tanah yang mampu memperbaiki sifat fisika, kimia, dan biologi tanah yang selanjutnya dapat memperbaiki pertumbuhan dan meningkatkan hasil tanaman (Chan dkk., 2007). Salah satunya sifat fisika tanah yaitu meningkatkan dan memantapkan agregat yang telah terbentuk dalam tanah Ultisol. Agregat tanah yang mantap akan mempertahankan sifat-sifat tanah yang baik untuk pertumbuhan tanaman dan ketersediaan air lebih lama dibandingkan dengan agregat tanah tidak mantap. Hingga saat ini belum ada penelitian mengenai pengaruh pupuk organonitrofos pada tanah Ultisol terhadap kemantapan agregat tanah, karena penelitian yang telah banyak dilakukan adalah 
tentang pupuk organonitrofos terkait sifat kimia dan biologinya. Oleh karena itu dilakukan penelitianini untuk mengetahui pengaruh pemberian pupuk organonitrofos terhadap kemantapan agregat pada tanah Ultisol.

Penelitian ini bertujuan untuk mengetahui kombinasi pupuk organonitrofos dan pupuk kimia dengan penambahan biochar yang paling efisien untuk memperbaiki kemantapan agregat tanah.

\section{METODE PENELITIAN}

Penelitian ini dilaksanakan di dua lokasi. Lokasi pertama di kebun percobaan BPTP (Balai Pengkajian Teknologi Pertanian) Provinsi Lampung yang terletak di Desa Negara Ratu Kecamatan Natar Kabupaten Lampung Selatan. Penelitian dilaksanakan dari Juni 2016 sampai dengan September 2016. Lokasi kedua di kebun percobaan Taman Bogo Lampung Timur.Penelitian dilaksanakan dari April sampai dengan Juli 2016.

Bahan yang digunakan yaitu benih kacang tanah varietas Jerapah, benih jagung varietas Bonanza F1, pupuk organonitrofos, biochar yang terbuat dari sekam padi, dolomit, pupuk urea, KCl, dan SP-36. Alat yang digunakan meliputi: kantong plastik, cangkul, meteran, gunting, ember, kertas label alat tulis dan peralatan analisis sifat fisika tanah di laboratorium.

Rancangan perlakuan yang digunakan dalam penelitian ini adalah Rancangan Acak Kelompok (RAK) dengan 11 perlakuan dan 3 ulangan di masingmasing lokasi, sehingga terdapat 33 petak percobaan. Untuk menguji homogenitas ragam digunakan uji Bartlett dan aditifitas data diuji dengan menggunakan uji Tukey. Jika hasil tersebut memenuhi asumsi, maka data dianalisis dengan sidik ragam dan dilakukan pengujian pemisahan nilai tengah perlakuan dengan uji Beda Nyata Terkecil (BNT) pada taraf 5\%. Untuk asumsi yang tidak terpenuhi maka dilakukan uji standar deviasi.

Variabel utama yang diamati adalah kemantapan agregat dengan metode ayakan ganda (ayakan kering dan ayakan basah). Dasar metode ini adalah mencari perbedaan rata rata berat diameter agregat pada pengayakan kering dan pengayakan basah, metode pengayakan kering dan pengayakan basah merupakan suatu cara untuk menetapkan kemantapan agregat (Balai Penelitian Tanah, 2006). Variabel pendukung yang diamati dalam penelitian ini adalah C-organik tanah dan tekstur tanah.

\section{HASIL DAN PEMBAHASAN}

Penelitian ini dilaksanakan di dua lokasi. Lokasi pertama di kebun percobaan BPTP (Balai Pengkajian Teknologi Pertanian) Provinsi Lampung yang terletak di Desa Negara Ratu Kecamatan Natar Kabupaten Lampung Selatan dengan tekstur tanah masing-masing fraksiyaitu liat $31 \%$, debu $15 \%$ dan pasir 54\% (Prasetiaswati dkk., 2012). Lokasi kedua di kebun percobaan Taman Bogo Lampung Timur dengan tekstur tanah masing-masing fraksi yaitu liat $41 \%$, debu $9 \%$ dan pasir 50\% (Ardiyani dkk., 2015).

Hasil penelitian menunjukkan bahwa, kemantapan agregat disetiap perlakuan memiliki kualitatif yang sama yaitu agak mantap, baik pada perlakuan menggunakan pupuk organik maupun pupuk kimia. Kemantapan agregat tanah merupakan sifat fisik tanah yang penting. Karena mempengaruhi fungsi tanah 
Tabel 1. Perlakuan aplikasi pupuk organonitrofos (OP), dan pupuk kimia di kebun percobaan BPTP (Balai Pengkajian Teknologi Pertanian) dengan menggunakan tanaman kacang tanah

\begin{tabular}{llcccc}
\hline \multirow{2}{*}{ Perlakuan } & \multicolumn{5}{c}{ Dosis $\left(\mathbf{K g ~ h a}^{\mathbf{- 1}}\right)$} \\
\cline { 2 - 5 } & Urea & SP-36 & KCl & OP \\
\hline P0 $=$ Kontrol & 50 & 150 & 100 & - \\
P1 $=100 \%$ NPK & 0 & 0 & 0 & 10.000 \\
P2 $=100 \%$ OP & 12,5 & 37,5 & 25 & 10.000 \\
P3 $=25 \%$ NPK + 100 \% OP & 25 & 75 & 50 & 10.000 \\
P4 $=50 \%$ NPK + 100 \% OP & 37,5 & 112,5 & 75 & 10.000 \\
P5 $=75 \%$ NPK + 100 \% OP & 50 & 150 & 100 & 10.000 \\
P6 $=100 \%$ NPK + 100 \% OP & 37,5 & 112,5 & 75 & 2.500 \\
P7 $=75 \%$ NPK + 25\% OP & 37,5 & 112,5 & 75 & 5.000 \\
P8 $=75 \%$ NPK + 50 \% OP & 37,5 & 112,5 & 75 & 7.500 \\
P9 $=75 \%$ NPK + 75 \% OP & 25 & 75 & 50 & 5.000 \\
P10 $=50 \%$ NPK + 50 \% OP & & & & \\
\hline
\end{tabular}

Tabel 2. Perlakuan aplikasi pupuk organonitrofos (OP), dan pupuk kimia di kebun percobaan Taman Bogo Lampung Timur dengan menggunakan tanaman kacang tanah

\begin{tabular}{llcccc}
\hline \multicolumn{1}{c}{ Perlakuan } & \multicolumn{4}{c}{ Dosis $\left(\mathbf{K g ~ h a}^{\mathbf{- 1}}\right)$} \\
\cline { 2 - 5 } & Urea & SP-36 & KCl & OP \\
\hline P0 $=$ Kontrol & 600 & 300 & 150 & \\
P1 $=100 \%$ NPK & & & & 10.000 \\
P2 $=100 \%$ OP & 150 & 75 & 37,5 & 10.000 \\
P3 $=25 \%$ NPK + 100 \% OP & 300 & 150 & 75 & 10.000 \\
P4 $=50 \%$ NPK + 100 \% OP & 450 & 225 & 112,5 & 10.000 \\
P5 $=75 \%$ NPK + 100 \% OP & 600 & 300 & 150 & 10.000 \\
P6 $=100 \%$ NPK + 100 \% OP & 450 & 225 & 112,5 & 2.500 \\
P7 $=75 \%$ NPK + 25 \% OP & 450 & 225 & 112,5 & 5.000 \\
P8 $=75 \%$ NPK + 50 \% OP & 450 & 225 & 112,5 & 7.500 \\
P9 $=75 \%$ NPK + 75 \% OP & 300 & 150 & 75 & 5.000 \\
P10 $=50 \%$ NPK + 50 \% OP & & & & \\
\hline
\end{tabular}

dalam menyediakan air, udara dan unsur hara bagi pertumbuhan tanaman (Suwardji dan Eberbach, 1998). Tanah dengan kemantapan agregat yang lemah dan miskin bahan organik memiliki kemampuan resistensi tanah dan air yang rendah sehingga kondisi fisik seperti ini menyebabkan rendahnya efisiensi pemupukan (Suwardji dkk., 2007).

Pengaruh aplikasi pupuk organonitrofos (OP), dan pupuk kimia terhadap agregat tanah di kebun percobaan BPTP (Balai Pengkajian Teknologi Pertanian) menunjukkan bahwa P0 (kontrol) memiliki nilai indeks kemantapan agregat terendah yaitu 50,04 sedangkan perlakuan $100 \%$ NPK + $100 \%$ OP (P6) memiliki nilai indeks kemantapan agregat tertinggi yaitu 52,26. Kemantapan agregat pada setiap perlakuan termasuk kedalam kriteria agak mantap. Hasil ini 
menunjukkan bahwa perlakuan pemberian pupuk organonitrofos dan pupuk kimia tidak terlalu berpengaruh karena hasil analisis nilai kriteria tertinggi dibandingkan dengan kontrol sama yaitu agak mantap. Sedangkan agregat di kebun percobaan Taman Bogo Lampung Timur menunjukkan bahwa bahwa P1 (100\% NPK) memiliki nilai indeks kemantapan agregat 50,19 sedangkan perlakuan $75 \%$ NPK $+25 \%$ OP (P7) memiliki nilai indeks kemantapan agregat tertinggi yaitu 53,14 . Kemantapan agregat pada setiap perlakuan termasuk kedalam kriteria agak mantap.Hasil ini menunjukkan bahwa perlakuan pemberian pupuk organonitrofos dan pupuk kimia tidak terlalu berpengaruh karena hasil analisis nilai kriteria tertinggi dibandingkan dengan kontrol sama yaitu agak mantap.

Kemantapan agregat tanah dipengaruhi oleh kandunganC-organik. C-organik merupakan penyusun bahan organik. Bahan organik berperan dalam memperbaiki sifat fisika tanah untuk menaikan kemantapan agregat tanah, memperbaiki struktur tanah serta dapat meningkatkan laju infiltrasi tanah. Hal ini karena bahanorganik menjadikan tanah semakin gembur, mendorong aktivitas mikroorganisme dalam tanah sehingga mempercepat terbentuknya agregat tanah yang lebih baik (Rickman dkk., 2001). Bahan organik sangat berperan dalam proses pembentukan agregat tanah. Bahan organik yang mengalami proses dekomposisi akan menghasilkan senyawa-senyawa organik seperti asam-asam organik dan humus yang dapat merekatkan butir-butir fraksi penyusun tanah menjadi kesatuan agregat yang utuh.

Pengaruh aplikasi pupuk organonitrofos (OP) dan pupuk kimia terhadap C- organik di kebun percobaan BPTP dengan menggunakan tanaman kacang tanah menunjukkan nilai C-organik yang rendah, pada perlakuan P0 (kontrol) memiliki nilai indeks C- organik terendah yaitu 0.69. Sedangkan perlakuan $25 \% \mathrm{NPK}+100 \%$ OP (P3) memiliki nilai tertinggi yaitu 1,03 dan jugatermasuk dalam kriteria rendah. Hasil ini menunjukkan bahwa perlakuan pemberian pupuk organonitrofos dan pupuk kimia berpengaruh karena hasil analisis nilai kriteria pada kontrol dan P3 berbeda. Sedangkan di kebun percobaan Taman Bogo Lampung Timur dengan menggunakan tanaman jagung manis nilai C- organik paling rendah pada perlakuan P1(100\% NPK) yaitu 0.76. Sedangkan perlakuan $100 \%$ NPK $+100 \%$ OP memiliki nilai tertinggi yaitu 1,77 termasuk dalam kriteria rendah. Hasil ini menunjukkan bahwa perlakuan pemberian pupuk organonitrofos dan pupuk kimia berpengaruh karena hasil analisis nilai kriteria pada kontrol dan P7 berbeda. Perbaikan agregat tanah dapatmenyebabkan kepekaan tanah terhadap erosi menurun.

Hasil penelitian menunjukkan bahwa kemantapan agregat tanah di Taman Bogo Lampung Timur lebih baik daripada kemantapan agregat tanah di BPTPNatar. Hal ini disebabkan oleh jenis tanaman di kedua lokasi tersebut. Penelitian di Taman Bogo menggunakan tanaman jagung manis, sedangkan penelitian di BPTPNatar menggunakan tanaman kacang tanah, menurut Kemper dan Rosenau (1986) salah satu faktor yang mempengaruhi kemantapan agregat tanah penutupan tajuk tanaman pada permukaan tanah yang 


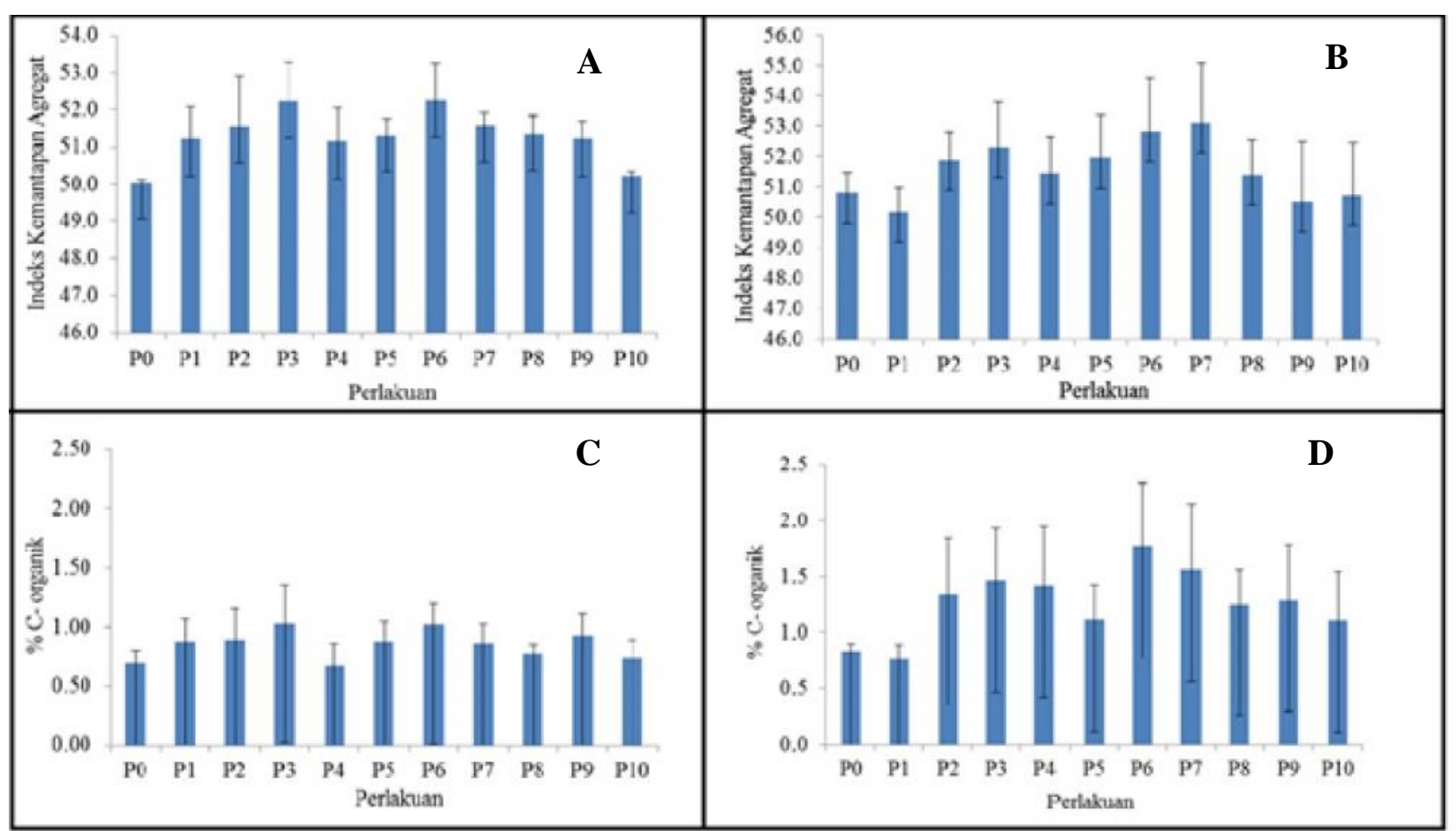

Gambar 1. Pengaruh perlakuan kombinasi pupuk organonitrofos dan pupuk kimia terhadap kemantapan agregat tanah di kebun percobaan BPTP Natar (A), Pengaruh perlakuan kombinasi pupuk organonitrofos dan pupuk kimia terhadap kemantapan agregat tanah di kebun percobaan Taman Bogo Lampung Timur (B), Pengaruh perlakuan kombinasi pupuk organonitrofos dan pupuk kimia terhadap C-organik tanah di kebun percobaan BPTP Natar ( C), Pengaruh perlakuan kombinasi pupuk organonitrofos dan pupuk kimia terhadap C-organik tanah di kebun percobaan Taman Bogo Lampung Timur (D).

dapat menghindari splash erotion. Pada lokasi Taman Bogo dengan jenis tanaman jagung kondisi tanah lebih ternaungi serta perakaran lebih dalam dan luas.Sebaliknya pada lokasi BPTP Natar tanah tidak ternaungi secara penuh dan perakaran lebih sempit dibandingkan jagung karena menggunakan tanaman kacang tanah.

Kemantapan agregat tanah juga dipengaruhi oleh faktor endogen pembentuk agregat tanah diantaranya adalah bahan organik tanah, kalsium, magnesium, natrium dapat ditukar dan tekstur tanah,klei dan pasir. Jumlah bahan organik tanah dapat dipengaruhi oleh berbagai faktor, diantaranya adalah faktor penggunaan lahan terkait banyaknya sisa tanaman yang dapat disumbangkan ke tanah dari vegetasi yang tumbuh di atasnya dan jenis pengolahan tanah yang diaplikasikan pada lahan tersebut. Kalsium dapat ditukar berpengaruh nyata terhadap kemantapan agregat karena merupakan kation bivalen yang dapat mempengaruhi struktur tanah dengan menjadi jembatan kationik antara klei dengan karbon organik tanah. Selain kalsium, magnesium merupakan kation yang dapat berfungsi sebagai bahan pengikat sehingga agregat tanah lebih tahan terhadap peruraian saat terjadi 
gangguan pada agregat. Natrium dapat ditukar menyebabkan tolakan dengan partikel tanah yang berdekatan akibat kesamaan muatan dan disintegrasi ped-ped. Klei yang jenuh dengan ion $\mathrm{Na}$ akan terdispersi sehingga ketahanan rerata agregat tanahnya lebih kecil dalam melawan peruraian karena gangguan. Sebagaimana faktor pembetuk agregat tanah yang lainnya, pengaruh pasir lebih besar daripada pengaruh klei. Hal ini ditunjukkan oleh nilai $P$-value klei yakni 0.030 dan $P$-value pasir yakni 0.006 . Pasir berpengaruh nyata terhadap kemantapan agregat tanah Latosol karena partikel pasir dapat saling berikatan lebih kuat melalui penyatuan dan penyelimutan oleh klei bersama-sama dengan bahan organik (Serly, 2013).

\section{KESIMPULAN}

Kesimpulan yang diperoleh dari penelitian ini adalah (1) Kombinasi pupuk organonitrofos dan pupuk kimia dengan penambahan biochar yang paling efisien untuk memperbaiki kemantapan agregat tanah di lokasi BPTP adalah $100 \%$ NPK $+100 \%$ OP yaitu 52,260. (2) Kombinasi pupuk organonitrofos dan pupuk kimia dengan penambahan biochar yang paling efisien untuk memperbaiki kemantapan agregat tanah di Taman Bogo Lampung Timur adalah $75 \%$ NPK $+25 \%$ OP yaitu 53,143.

\section{DAFTAR PUSTAKA}

Allen, H. 2003. Arboreal histosols in old-growth coast redwood forests, northern California: genesis, soil nutrient availability, and water cycling studies., University of California, Davis, CA.
Ardiyani R. R, Sutono dan Sugeng, P. 2015. Perbaikan Retensi Air Typic Kanhapludult Taman Bogo dan Pertumbuhan Tanaman Jagung Melalui Pemberian Biochar Tempurung Kelapa Sawit. J. Tanah dan Sumberdaya Lahan. 2 (2): 199209.

Atmojo S. W. 2003. Peranan Bahan Organik Terhadap Kesuburan Tanah dan Upaya Pengelolaannya. Skripsi. Fakultas Pertanian Universitas Sebelas Maret. Surakarta. 36 hlm.

Chan K. Y., Van Z. L., Meszaros I., Downie A. and Joseph S. 2007. Agronomic values of green waste biochar as a soil amendment. Australian J. of Soil Research. 45: 629-634.

Leiwakabessy, F. M. dan A. Sutandi. 2004. Pupuk dan Pemupukan.Departemen Tanah Fakultas Pertanian. Institut Pertanian Bogor, Bogor. 208 hlm.

Nurida dan Undang K. 2009. Perubahan Agregat Tanah pada Ultisols Jasinga Terdegradasi Akibat Pengolahan Tanah. J. Tanah dan Iklim. 5 (30) : 37-46.

Prahastuti, S. W. 2005. Perubahan Beberapa Sifat Kimia dan Serapan P Jagung Akibat Pemberian Bahan Organik dan Batuan Posfat Alam Pada Tanah Ultisol Jasinga. J. Agroland. 12 (1): 68 -74 .

Prasetiaswati N, dan Budhi S. R. 2012. Kelayakan Usahatani Ubi Jalar dengan Penerapan Teknologi Pengguludan di Lahan Kering Masam di Lampung. J. Penelitian Pertanian Tanaman Pangan. 31(3): 188 - 194. 
Rickman R. W., C. L. Douglas, Jr., S. L. Albrecht L. G. Bundy and J. L. Berc. 2001. CQESTR: a model to estimate carbon sequestration in agricultural soils. J. Soil and Water Cons. 56 (3) :237-242.

Serly A.P. 2013. Pengaruh Faktor PembentukAgregat TanahTerhadap Kemantapan Agregat Tanah Latosol Dramaga Pada Berbagai Penggunaan Lahan.Skripsi. Fakultas Pertanian Institut Pertanian Bogor. Bogor. $33 \mathrm{hlm}$.

Suntoro W. A. 2003. Peranan Bahan Organik Terhadap Kesuburan Tanah dan Upaya Pengelolaannya. Pidato Pengukuhan Guru Besar Ilmu Kesuburan Tanah Fakultas Pertanian Universitas Sebelas Maret. Surakarta. $36 \mathrm{Hlm}$.
Suprayogo, D., Widianto, Purnomosidi, P., Widodo, R. H., Rusiana, F., Aini, ZZ., Khasanah, N., dan Kusuma, Z. 2004. Degradasi Sifat Fisik Tanah Sebagai Akibat Alih Guna Lahan Hutan Menjadi Sistem Kopi Monokultur: Kajian Perubahan Makro porositas Tanah. J.Agrivita. 26 (1):60-68.

Suwardji dan Eberbach, P. L. 1998. Seasonal changes of physical properties of an Oxic Paleustalf after 16 years of direct drilling or conventional cultivation. J. Soil and TillageResearch. 49: 65-77.

Suwardji, Suardiari, G. dan Hippi, A. 2007. Meningkatkan efisiensi air irigasi dari sumber air tanah dalam pada lahan kering pasiran Lombok Utara menggunakan teknologi irigasi sprinkler big gun. Prosiding Kongres Nasional HITI IX, 5-7 Desember 2007. Yogyakarta. 